www.jmscr.igmpublication.org

Impact Factor (SJIF): 6.379

Index Copernicus Value: 71.58

ISSN (e)-2347-176x ISSN (p) 2455-0450

crossref DOI:_https://dx.doi.org/10.18535/jmscr/v6i5.14

Journal Of Medical Science And Clinical Research

IGM Publication

An Official Publication of IGM Publication

\title{
Comparative Evaluation of the Effect of Vitamin D Supplementation in Pregnancy and its Correlation with Fetomaternal Outcome
}

\author{
Authors \\ Preeti Agrawal $^{1}$, Kamlesh Yadav ${ }^{2}$, Swati Falodia ${ }^{3}$, Shweta Chaudhary ${ }^{4}$ \\ ${ }^{1}$ Resident, ${ }^{2}$ Professor, ${ }^{3}$ Professor, ${ }^{4}$ Assistant Professor \\ Department of Obstetrics \& Gynaecology, Sardar Patel Medical College \& AGH, Bikaner, Rajasthan \\ Corresponding Author \\ Preeti Agrawal \\ Resident, Department of Obstetrics \& Gynaecology, Sardar Patel Medical College \& AGH, Bikaner, \\ Rajasthan \\ Email: ruchitagrawal99@gmail.com
}

\begin{abstract}
Introduction: Vitamin D deficiency is a common and increasing problem and concerns have been raised that there may be an epidemic of such deficiency in pregnancy. Vitamin D may be important in the pathogenesis of severe preeclampsia \& preterm birth.
\end{abstract}

Aim: The aim of the present study was to estimate the association between intake of vitamin $D$ during pregnancy and the risk of preeclampsia \& preterm birth.

Method: We performed a prospective observational study in 200 pregnant women with singleton pregnancy at 12-16 weeks of gestational age as cases, Serum vitamin D tested at 1st trimester \& again in 3rd trimester. Observations for antenatal complications like preeclampsia and foetal outcome was done and correlated to serum vitamin D levels among those who took the supplementation and those who did not, and analyzed.

Result: The mean vitamin D level was $16.76 \pm 6.56 \mathrm{ng} / \mathrm{ml}$. Supplementation was done in 40 vitamin D deficient women. The mean vitamin D level in the 1 st trimester increased from 13.74 \pm 4.84 to $27.12 \pm 7.19$ in $3 r d$ trimester $(p$ value $=0.0001)$. According to serum vitamin $D$ in $3 r d$ trimester, the incidence of preeclampsia was found much higher in vitamin D deficiency $(<20 \mathrm{ng} / \mathrm{ml})$ group i.e. $28(36.36 \%)$ as compared with vitamin D insufficiency $(20-30 \mathrm{ng} / \mathrm{ml})$ group i.e. 3(4.17\%). No case of preeclampsia in vitamin D sufficiency (>30 $\mathrm{ng} / \mathrm{ml}$ ) group. Incidence of Preterm Baby was found slightly higher in vitamin D deficiency (<20 $\mathrm{ng} / \mathrm{ml})$ group i.e. 20(25.97\%) as compared with vitamin D insufficiency $(20-30 \mathrm{ng} / \mathrm{ml}) \mathrm{group}$ i.e. 16(22.22\%). 2 case(3.92\%) of Preterm Baby was found in vitamin D sufficiency (>30 $\mathrm{ng} / \mathrm{ml}) \mathrm{group}$.

Conclusion: High prevalence of vitamin D deficiency in pregnancy was found in our study. Higher vitamin $D$ levels $(>30 \mathrm{ng} / \mathrm{ml})$ is associated with better fetomaternal outcome. Supplementation of vitamin $D$ in pregnancy is safe \& should be given.

Keywords: Vitamin D supplementation; Preeclampsia; Preterm birth.

\section{Introduction}

Vitamin D deficiency or insufficiency is currently a global pandemic affecting all ages and ethnic groups $^{1}$. Vitamin D is a fat soluble vitamin produced endogenously in the skin with exposure to sunlight. It is also obtained from consuming 
fortified milk or juice, fish oils, and dietary supplements of vitamin D that is ingested or produced in the skin must undergo hydroxylation in the liver to 25 hydroxyvitamin D $(25(\mathrm{OH}) \mathrm{D})$, then further hydroxylation primarily in the kidney to the physiologically active 1,25 dihydroxyvitamin $\mathrm{D}^{2}$.

Vitamin D insufficiency during pregnancy is associated with adverse maternal outcomes such as increased risk of gestational diabetes mellitus (GDM), preeclampsia, caesarean-section delivery and bacterial vaginosis ${ }^{3}$. Preeclampsia and hypertensive disorders complicate $3-10 \%$ of pregnancies and contribute to maternal and neonatal morbidity and mortality ${ }^{4}$.

Pathogenesis of preeclampsia involves a number of biological processes that may be directly or indirectly affected by vitamin $\mathrm{D}$, including immune dysfunction, placental implantation, abnormal angiogenesis, excessive inflammation, and hypertension ${ }^{5}$. Vitamin $\mathrm{D}$ has been hypothesized to influence preeclampsia risk. Preeclampsia rates are elevated during winter months, when sunlight-dependent $25(\mathrm{OH})$ D productions are reduced.

Women with vitamin D deficiency have a 2.4 fold increased risk of having a small for gestational age baby ${ }^{6}$. Women who were vitamin D deficient in the $1^{\text {st }}$ trimester of pregnancy 14 weeks or less were twice as likely to have babies who fell in the lower $10^{\text {th }}$ percentile for weight when compared to other full term babies born in the same week of pregnancy, a condition known as "small for Gestational age".

This study evaluates the effect of vitamin D supplementation on fetomaternal outcome in pregnant women.

\section{Material \& Methods}

After approval by the Institute Ethics Committee \& written informed consent from patient's parents, the study was conducted as hospital based prospective observational study in a total of 200 pregnant women with singleton pregnancy at 1216 weeks of gestational age as cases.

\section{Inclusion Criteria}

1. All women with singleton pregnancy booked in 12-16 weeks of pregnancy.

2. Women without any medical problems, non-smokers and not taking any medication will be included in the study.

\section{Exclusion Criteria}

1. Severe anaemia

2. Twin pregnancy

3. Alcohol \& tobacco use

4. Chronic hypertension

5. Angina pectoris

6. Previous myocardial infarction

7. Heart failure

8. Chronic obstructive pulmonary disease

9. Diabetes mellitus

10. Previous LSCS

11. Known case of Hypovitaminosis

12. Chronic Renal disease

13. Chronic Hepatic disease

14. Known cases of hyper parathyroid

15. Malabsorption syndrome

16. Women on anti tubercular drugs, anti epileptics, steroids

Serum vitamin D levels were tested at 12-16 weeks of pregnancy. Women found deficient (vitamin D $<20 \mathrm{ng} / \mathrm{ml}$ ) or insufficient (vitamin D 20-30ng/ml) were counseled about the potential harms of vitamin D deficiency and supplementation, its benefits. Final choice for supplementation was left on the patient. Supplementation with 60,000 IU Cholecalciferol per week for 8 weeks followed by monthly supplemental dose of same was done in vitamin D deficient women. Only women without co morbidities, non-smokers, and before starting any medication was asked to take part in the study. Based on clinical laboratory classification, deficiency was defined as total circulating $25(\mathrm{OH})$ D level of less than $20 \mathrm{ng} / \mathrm{ml}$, insufficiency as $>=20$ to $<30 \mathrm{ng} / \mathrm{ml}$ and sufficiency as $>=30 \mathrm{ng} / \mathrm{ml}$.

Serum vitamin D was tested again in all subjects during 32 weeks of gestational age, observation for antenatal complications like preeclampsia and preterm birth and foetal outcome was done. 


\section{Results}

In our study maximum numbers of cases were in 21-25 years age group with $102(51 \%)$ women. 26-30 years age group had $54(27 \%)$ women, $\leq 20$ years age group had 36 ( $18 \%$ ) women and $>30$ years age group had 8 (4\%) women(fig 1). Mean age in the study was $24.185 \pm 3.552$ years.

In our study, 140 women $(70 \%)$ were found to have Vitamin D Deficiency $(<20 \mathrm{ng} / \mathrm{ml})$ out of which $82(84.54 \%)$ women had taken vitamin D supplementation and $58(56.31 \%)$ not, 45 women (22.5\%) were Vitamin D Insufficiency (20-30 $\mathrm{ng} / \mathrm{ml})$ out of which 15 (15.46\%) women had taken vitamin D supplementation and $30(29.13 \%)$ not. Only 15 women $(7.5 \%)$ were found to have sufficient Vitamin D Levels (>30 ng/ml) (table 1). Supplementation was done in 97 vitamin D deficient women. It increased mean vitamin D levels from $13.74 \pm 4.84$ to $27.12 \pm 7.19$ from first to third trimester $(\mathrm{p}$ value $=0.0001)$. Mean Vitamin D Levels in $3^{\text {rd }}$ trimester was found slightly higher $(19.95 \mathrm{ng} / \mathrm{ml})$ than the $1^{\text {st }}$ trimester levels $(19.61 \mathrm{ng} / \mathrm{ml})$ in vitamin D NOT supplementation group.
The incidence of preeclampsia was found much higher in vitamin D deficiency $(<20 \mathrm{ng} / \mathrm{ml})$ group i.e. $28(36.36 \%)$ as compared with vitamin D insufficiency (20-30 ng/ml) group i.e. 3(4.17\%). There was no case of preeclampsia in vitamin $D$ sufficiency $(>30 \mathrm{ng} / \mathrm{ml})$ group $(\mathrm{p}$ value $=0.0001)$. incidence of Preterm Baby was found slightly higher in vitamin D deficiency $(<20 \mathrm{ng} / \mathrm{ml})$ group i.e. $20(25.97 \%)$ as compared with vitamin D insufficiency $(20-30 \quad \mathrm{ng} / \mathrm{ml})$ group i.e. 16(22.22\%). There was 2 (3.92\%) case of Preterm Baby was found in vitamin D sufficiency (>30 $\mathrm{ng} / \mathrm{ml})$ group $(\mathrm{p}$ value $=0.001)($ table 2,3$)$.

Maximum no. of cases ( $48 \& 20$ i.e. total 68) having birth weight $>2.5 \mathrm{~kg}$ are in the Vitamin D supplementation group, while maximum no. of cases (34 \& 39 i.e. total 73) having birth weight $<2.5 \mathrm{~kg}$ are in the Vitamin D not supplementation group ( $\mathrm{p}$ value $=0.0033$ ). Mean Birth Weight (in $\mathrm{kg}$ ) was found higher $(2.60 \pm 0.59 \mathrm{~kg})$ in patients who were supplemented with Vitamin D than in Vitamin D NOT Supplementation Group $(2.25 \pm 0.63 \mathrm{~kg})(\mathrm{p}$ value $=0.0006)($ table 4$)$.

Figure 1: Distribution of cases according to Age (in yrs)

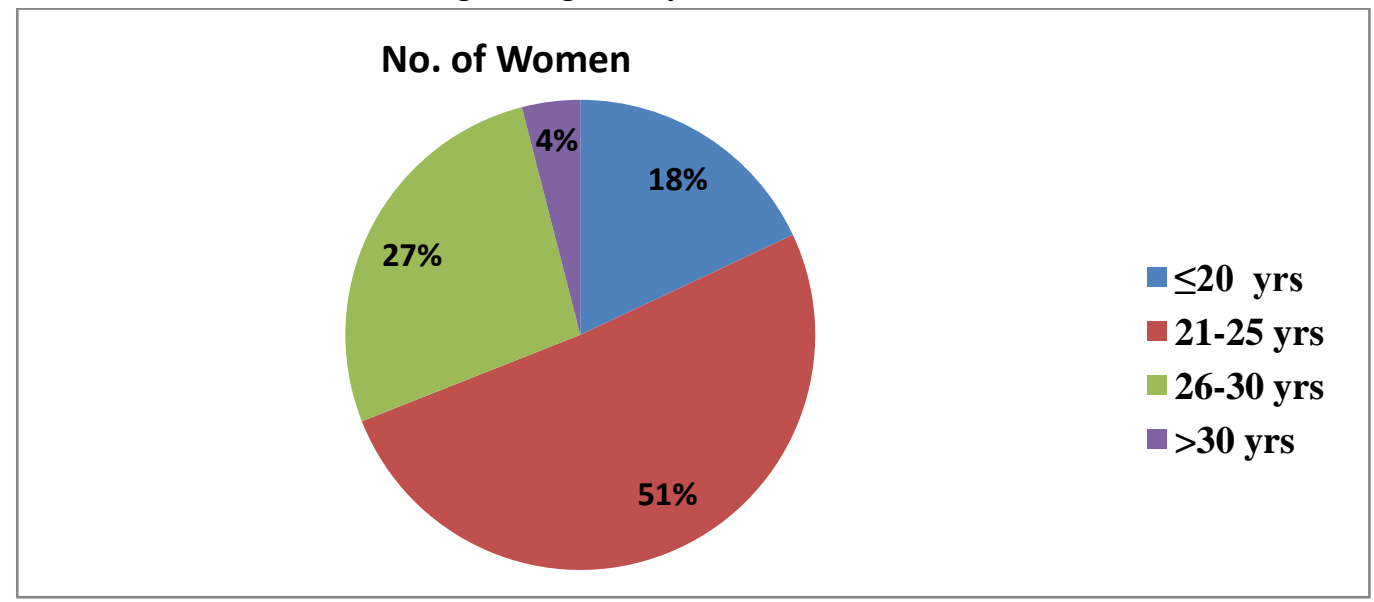

Table 1: Distribution of cases according to vitamin D Levels (ng/ml)

\begin{tabular}{|c|c|c|c|c|c|}
\hline & \multicolumn{4}{|c|}{$1^{\text {st }}$ trimester Vitamin D Levels (ng/ml) } \\
\hline & & $\begin{array}{c}\text { Vitamin D } \\
\text { Deficiency }(<20 \\
\text { ng/ml })\end{array}$ & $\begin{array}{c}\text { Vitamin D } \\
\text { Insufficiency (20-30 } \\
\text { ng/ml) }\end{array}$ & $\begin{array}{c}\text { Vitamin D } \\
\text { Sufficiency }(>\mathbf{3 0} \\
\mathrm{ng} / \mathrm{ml})\end{array}$ & Total \\
\hline \multirow{4}{*}{ Supplementation } & \multirow{2}{*}{ YES } & 82 & 15 & 0 & 97 \\
\hline & & $84.54 \%$ & $15.46 \%$ & $0 \%$ & $100 \%$ \\
\hline & \multirow{2}{*}{ NO } & 58 & 30 & 15 & 103 \\
\hline & & $56.31 \%$ & $29.13 \%$ & $14.56 \%$ & $100 \%$ \\
\hline \multicolumn{2}{|l|}{ Total } & 140 & 45 & 15 & 200 \\
\hline
\end{tabular}


Table 2: Distribution of Incidence of Preeclampsia according to $3^{\text {rd }}$ trimester Vitamin D Levels (ng/ml)

\begin{tabular}{|c|c|c|c|c|c|c|c|c|}
\hline & \multicolumn{7}{|c|}{$3^{\text {rd }}$ trimester Vitamin D Levels (ng/ml) } \\
\hline & & \multicolumn{2}{|c|}{$\begin{array}{c}\text { Vitamin D } \\
\text { Deficiency }(<20 \\
\text { ng/ml) }\end{array}$} & \multicolumn{2}{|c|}{$\begin{array}{c}\text { Vitamin D } \\
\text { Insufficiency (20-30 } \\
\text { ng/ml) }\end{array}$} & \multicolumn{2}{|c|}{$\begin{array}{c}\text { Vitamin D } \\
\text { Sufficiency }(>\mathbf{3 0} \\
\text { ng/ml) }\end{array}$} & \multirow[t]{2}{*}{ Total } \\
\hline & & No. & $\%$ & No. & $\%$ & No. & $\%$ & \\
\hline \multirow[t]{2}{*}{ Preeclampsia } & YES & 28 & $36.36 \%$ & 3 & $4.17 \%$ & 0 & $0 \%$ & 31 \\
\hline & NO & 49 & $63.64 \%$ & 69 & $95.83 \%$ & 51 & $100 \%$ & 169 \\
\hline \multicolumn{2}{|l|}{ Total } & 77 & $100 \%$ & 72 & $100 \%$ & 51 & $100 \%$ & 200 \\
\hline \multicolumn{2}{|l|}{ P Value } & \multicolumn{7}{|c|}{0.001} \\
\hline
\end{tabular}

Table 3: Distribution of Preterm Birth according to $3^{\text {rd }}$ trimester vitamin D Levels (ng/ml)

\begin{tabular}{|c|c|c|c|c|c|c|c|c|}
\hline & \multicolumn{7}{|c|}{$3^{\text {rd }}$ trimester Vitamin D Levels (ng/ml) } \\
\hline & & \multicolumn{2}{|c|}{$\begin{array}{c}\text { Vitamin D } \\
\text { Deficiency }(<20 \\
\text { ng/ml) }\end{array}$} & \multicolumn{2}{|c|}{$\begin{array}{c}\text { Vitamin D } \\
\text { Insufficiency (20-30 } \\
\text { ng/ml) }\end{array}$} & \multicolumn{2}{|c|}{$\begin{array}{c}\text { Vitamin D } \\
\text { Sufficiency (>30 } \\
\text { ng/ml) }\end{array}$} & \multirow[t]{2}{*}{ Total } \\
\hline & & No. & $\%$ & No. & $\%$ & No. & $\%$ & \\
\hline \multirow{2}{*}{ Preterm Baby } & YES & 20 & $25.97 \%$ & 16 & $22.22 \%$ & 2 & $3.92 \%$ & 38 \\
\hline & NO & 57 & $74.03 \%$ & 56 & $77.78 \%$ & 49 & $96.08 \%$ & 162 \\
\hline \multicolumn{2}{|l|}{ Total } & 77 & $100 \%$ & 72 & $100 \%$ & 51 & $100 \%$ & 200 \\
\hline \multicolumn{2}{|l|}{ P Value } & \multicolumn{7}{|c|}{0.001} \\
\hline
\end{tabular}

Table 4: Distribution of Cases According To Birth Weight \& Vit D Supplementation

\begin{tabular}{|l|c|c|c|}
\hline \multirow{2}{*}{ Birth Weight (in kg) } & \multicolumn{2}{|c|}{ Vit D Supplementation } & \multirow{2}{*}{ P Value } \\
\cline { 2 - 3 } & YES & NO & \\
\hline$\leq \mathbf{2} \mathbf{~ k g}$ & 16 & 34 & 0.0033 \\
\hline $\mathbf{2 . 1}-\mathbf{2 . 5} \mathbf{~ k g}$ & 13 & 39 & \\
\hline $\mathbf{2 . 5}-\mathbf{3 . 0} \mathbf{~ k g}$ & 48 & 18 & \\
\hline$>\mathbf{3 . 0} \mathbf{~ k g}$ & 20 & 12 & \\
\hline TOTAL & 97 & 103 & \\
\hline
\end{tabular}

\section{Discussion}

The prevalence of Vitamin D deficiency in pregnancy and its association with preeclampsia and preterm birth have attracted much public health attention. In the present study, we sought to determine whether vitamin $D$ deficiency is associated with an increased risk of adverse fetomaternal outcome. Our results confirmed our hypothesis that women who developed preeclampsia \& preterm babies had significantly lower maternal serum vitamin D levels early in pregnancy compared with healthy women with uncomplicated term pregnancies.

Our findings confirm and extend earlier work by Bodnar et $\mathrm{al}^{7}$, where vitamin D deficiency early in pregnancy was associated with preeclampsia. The investigators reported a dose-response relationship, with $25(\mathrm{OH}) \mathrm{D}$ levels of less than $37.5 \mathrm{nmol} /$ liter being associated with a 5-fold increase in the odds of preeclampsia (adjusted OR, 5.0; 95\% CI, 1.7-14.1).
In a prospective cohort study by Haugen et $\mathrm{al}^{8}$. involving more than 20,000 nulliparous women, a $29 \%$ reduced risk of preeclampsia was observed in women who reported supplementing with 400 600 IU of vitamin D during the first half of their pregnancies.

Marya et $a l^{9}$. conducted a randomized controlled trial of calcium and vitamin D supplementation (1200 IU/d) beginning at 20-24 wk gestation in 400 women. Although the supplemented group experienced a significant reduction in blood pressure and their incidence of preeclampsia was lower than the control group (6 vs.9\%), the preeclampsia results were not statistically significant.

Wei et $\mathrm{al}^{10}$ did a meta-analysis of four observational studies showed that pregnant women with vitamin D deficiency experienced an increased risk of Preterm birth $(\mathrm{OR}=1.58,95 \%$ CI: $1.08-2.31$ ) 
Wagner et $\mathrm{al}^{11}$. showed that achieving a $25(\mathrm{OH}) \mathrm{D}$ serum concentration $\geq 40 \quad \mathrm{ng} / \mathrm{mL}$ could significantly decrease the risk of PTB compared to concentrations $\leq 20 \mathrm{ng} / \mathrm{mL}$ after maternal supplementation with vitamin D during pregnancy.

Our study does have several methodological strengths. The maternal serum was collected well before delivery at a time when no clinical manifestations of preeclampsia were evident reducing the likelihood that subclinical disease affected vitamin D levels. In addition, we excluded all women with chronic medical illnesses, such as diabetes and chronic hypertension. These diseases have been associated with increased risk for preeclampsia.

\section{Conclusion}

Our study shows an increasingly compelling evidence for a causal relationship between low vitamin D level and adverse maternal and neonatal outcomes. As in other fields of obstetrics endocrinology, there is a need for greater research in Vitamin D therapeutics in pregnancy. Vitamin D supplementation is simple and cost effective with low likelihood of toxicity, supplementation should be done in all pregnant women to keep serum levels of vitamin D in the normal range for adults (>30 ng/ml).

\section{References}

1 Holick MF, chen TC. Vitamin D deficiency; a worldwide problem with health consequences. Am J Clin Nutr. 2008; 87: 1080S-1086S.

2 Christopher $S$ Kovacs. Vitamin $D$ in pregnancy and lactation: maternal, fetal, and neonatal outcomes from human and animal studies. Am J Clin Nutr 2008;88 (suppl):520S- 8S.

3 Hollis BW, Wagner CL. Vitamin D and pregnancy: skeletal effects, non skeletal effects, and birth outcomes. Calcif Tissue Int2013;92:128-39.
4 Bodnar LM,Cator JM, Roberts JM. Racial/ethnic differences in the monthly variation of preeclampsia incidence. Am J obstetGynecol. 2007; 196: 321- 325.

5 Seely EW. Calciotrophic hormones in preeclampsia, a renewal of interest. J Clin Endocrinol Metab. 2007; 92: 3402-3403.

6 Leffelar ER, Vrijkotte TG, van Eijsden M. Maternal early pregnancy vitamin D status in relation to fetal and neonatal growth: results of multi-ethnic Amsterdam Born children and their development cohort.Br J Nutr. 2010; 104: 108-117

7 Bodnar LM, Catov JM, Simhan HN, Holick MF, Powers RW, Roberts JM 2007 Maternal vitamin D deficiency increases the risk of preeclampsia.J Clin Endocrinol Metab 92:3517-3522

8 Haugen M, Brantsaeter AL, Trogstad L, Alexander J, Roth C, Magnus P, MeltzerHM2009 Vitamin D supplementation and reduced risk of preeclampsia in nulliparous women. Epidemiology 20:720-726

9 Marya RK, Rathee S, Manrow M 1987 Effect of calcium and vitamin D supplementation on toxaemia of pregnancy. Gynecol Obstet Invest 24:3842

10 Wei, S.Q.; Qi, H.P.; Luo, Z.C.; Fraser, W.D. Maternal vitamin D status and adverse pregnancy outcomes: A systematic review and meta-analysis. J. Mater. Fetal Neonatal Med. 2013, 26, 889-899.

11 Wagner, C.L.; Baggerly, C.; McDonnell, S.; Baggerly, K.A.; French, C.B.; Baggerly, L.; Hamilton, S.A.; Hollis, B.W. Post-hoc analysis of vitamin D status and reduced risk of preterm birth in two vitamin D pregnancy cohorts compared with South Carolina March of Dimes 2009-2011 rates. J. Steroid Biochem. Mol. Biol. 2016, 155, 245-251. 